\title{
Lentibacillus salis sp. nov., a moderately halophilic bacterium isolated from a salt lake
}

\author{
Correspondence \\ Chang-Jin Kim \\ changjin@kribb.re.kr
}

\author{
Jae-Chan Lee, ${ }^{1}$ Wen-Jun Li, ${ }^{2,3}{\text { Li-Hua Xu, }{ }^{2} \text { Cheng-Lin Jiang }}^{2}$ \\ and Chang-Jin Kim ${ }^{1}$
}

\author{
${ }^{1}$ Functional Metabolomics Research Center, KRIBB, Daejeon 305-806, Republic of Korea \\ ${ }^{2}$ The Key Laboratory for Microbial Resources of the Ministry of Education, PR China, and \\ Laboratory for Conservation and Utilization of Bio-Resources, Yunnan Institute of Microbiology, \\ Yunnan University, Kunming, Yunnan 650091, PR China \\ ${ }^{3}$ Guangdong Key Laboratory of Marine Materia Medica, South China Sea Institute of Oceanology, \\ Chinese Academy of Sciences, Guangzhou 510301, PR China
}

Moderately halophilic, aerobic, Gram-positive rods are taxonomically diverse and have been isolated from various salty environments and related habitats, including solar salterns, saline soils and soda lakes (Oren, 2002). They are a diverse group of bacteria belonging to the genera Bacillus (Ventosa et al., 1989, 1998), Amphibacillus (Niimura et al., 1990), Halobacillus (Spring et al., 1996), Virgibacillus (Heyndrickx et al., 1998), Gracilibacillus (Wainø et al., 1999), Filobacillus (Schlesner et al., 2001), Jeotgalibacillus, Marinibacillus (Yoon et al., 2001), Oceanobacillus (Lu et al., 2001), Lentibacillus (Yoon et al., 2002), Paraliobacillus (Ishikawa et al., 2002), Marinilactobacillus (Ishikawa et al., 2003), Cerasibacillus (Nakamura et al., 2004), Tenuibacillus (Ren \& Zhou, 2005a), Pontibacillus (Lim et al., 2005a), Salinibacillus (Ren \& Zhou, 2005b), Thalassobacillus (García et al., 2005), Alkalibacillus (Jeon et al., 2005b), Halolactibacillus (Ishikawa et al., 2005), Caldalkalibacillus (Xue et al., 2006), Paucisalibacillus (Nunes et al., 2006), Terribacillus (An et al., 2007), Halalkalibacillus (Echigo

The GenBank/EMBL/DDBJ accession number for the 16S rRNA gene sequence of strain $B H 113^{\top}$ is $A Y 762976$. et al., 2007), Piscibacillus (Tanasupawat et al., 2007), Pelagibacillus (Kim et al., 2007) and Salsuginibacillus (Carrasco et al., 2007). Recently, the moderately halophilic species Bacillus halophilus (Ventosa et al., 1989) was reclassified within a novel genus designated Salimicrobium (Yoon et al., 2007).

The genus Lentibacillus includes Gram-variable rods able to produce spherical or oval endospores. Colonies are creamcoloured, catalase- and oxidase-positive and urease-negative. The cell-wall peptidoglycan contains meso-diaminopimelic acid, the predominant menaquinone is MK-7, the major polar lipids are diphosphatidylglycerol and phosphatidylglycerol, the major fatty acids are anteiso- $\mathrm{C}_{15: 0}$ and iso- $\mathrm{C}_{16: 0}$ and the $\mathrm{G}+\mathrm{C}$ content of the DNA is in the range $42-49 \mathrm{~mol} \%$. The genus Lentibacillus contains eight species, Lentibacillus salicampi (the type species) (Yoon et al., 2002), L. juripiscarius (Namwong et al., 2005), L. salarius (Jeon et al., 2005a), L. lacisalsi (Lim et al., 2005b), L. halophilus (Tanasupawat et al., 2006), L. kapialis (Pakdeeto et al., 2007), L. halodurans (Yuan et al., 2007) and L. salinarum (Lee et al., 2008). In this study, a novel Gram-positive bacterium, strain $\mathrm{BH} 113^{\mathrm{T}}$, belonging to the 
genus Lentibacillus was isolated from the soil of a salt lake in Xinjiang Province, China, and its taxonomic status was established using phenotypic and chemotaxonomic properties and 16S rRNA gene sequence analysis.

During the screening of halophilic bacteria, strain $\mathrm{BH} 113^{\mathrm{T}}$ was isolated from a soil sample collected in the summer of 2002 from the shore of Ayakekum salt lake $\left(37^{\circ} 34^{\prime} \mathrm{N} 89^{\circ}\right.$ $39^{\prime} \mathrm{E} ; 3879 \mathrm{~m}$ altitude) located in the Altun mountain range natural reserve in Xinjiang Uygur Autonomous Region in the west of China. The $\mathrm{pH}$ of the soil was in the range 8.2-9.3. Soil samples were diluted serially with $1 \%$ $(\mathrm{w} / \mathrm{v})$ saline solution and strain $\mathrm{BH} 113^{\mathrm{T}}$ was isolated on marine agar 2216 (MA; Difco) to which $10 \%(\mathrm{w} / \mathrm{v}) \mathrm{NaCl}$ had been added (final $\mathrm{NaCl}$ concentration: $11.94 \%$, w/v), at $35{ }^{\circ} \mathrm{C}$ for 3 days. Requirements for, and tolerance of, $\mathrm{NaCl}$ were determined in trypticase soy broth (TSB; containing the following, $\mathrm{l}^{-1}: 17.0 \mathrm{~g}$ casein, $3.0 \mathrm{~g}$ soybean meal, $2.5 \mathrm{~g}$ glucose, $5.0 \mathrm{~g}$ sodium chloride and $2.5 \mathrm{~g}$ dipotassium phosphate) supplemented with modified artificial seawater (ASW; containing the following, $1^{-1}: 0$ $30 \%, \quad w / v, \quad \mathrm{NaCl} ; \quad 5.94 \mathrm{~g} \quad \mathrm{MgSO}_{4} \cdot 7 \mathrm{H}_{2} \mathrm{O} ; \quad 4.53 \mathrm{~g}$ $\mathrm{MgCl}_{2} .6 \mathrm{H}_{2} \mathrm{O} ; 0.64 \mathrm{~g} \mathrm{KCl} ; 1.3 \mathrm{~g} \mathrm{CaCl}_{2}$ ). Optimum growth was tested at different temperatures $\left(4-55{ }^{\circ} \mathrm{C}\right)$ on MA containing $10 \%(\mathrm{w} / \mathrm{v}) \mathrm{NaCl}$ and at different $\mathrm{pH}$ values (5.0-11.0) in TSB supplemented with ASW containing $10 \%(\mathrm{w} / \mathrm{v}) \mathrm{NaCl}$. Anaerobic growth was determined in an anaerobic chamber $\left(\mathrm{H}_{2} / \mathrm{CO}_{2} / \mathrm{N}_{2}, \quad 5: 10: 85\right.$; Mart Microbiology) at $37{ }^{\circ} \mathrm{C}$ for 5 days on MA containing $10 \%(\mathrm{w} / \mathrm{v}) \mathrm{NaCl}$. Cell morphology and the flagellum type were studied using light microscopy and transmission electron microscopy as described by Lee et al. (2006). Motility was checked at 24 and $36 \mathrm{~h}$ in wet mounts by using a light microscope (E600; Nikon). The presence of endospores was determined using Schaeffer-Fulton stain (Smibert \& Krieg, 1981).

Gram staining was performed using the bioMérieux Gram stain kit according to the manufacturer's instructions. Catalase activity was determined by assessing the production of oxygen bubbles in $3 \%(\mathrm{v} / \mathrm{v})$ aqueous hydrogen peroxide solution. Oxidase activity was tested by assessing the oxidation of $1 \%(\mathrm{w} / \mathrm{v})$ tetramethyl $p$-phenylenediamine using a Bactident Oxidase strip (Merck). Nitrate reduction and hydrolysis of aesculin, casein, starch, Tween 80, urea, hypoxanthine, tyrosine and xanthine were determined on MA according to the methods described by Cowan \& Steel (1965), Lányí (1987) and Smibert \& Krieg (1994). Acid production from carbohydrates was tested as described by Leifson (1963); all suspension media were supplemented with ASW containing $10 \%(w / v) ~ \mathrm{NaCl}$.

On MA medium with $10 \%(\mathrm{w} / \mathrm{v}) \mathrm{NaCl}$, strain $\mathrm{BH} 113^{\mathrm{T}}$ formed light-yellow, low-convex, circular colonies. It showed a moderately halophilic response, growing in TSB containing 5-15\% (w/v) NaCl; optimum growth occurred in TSB with $10 \%(\mathrm{w} / \mathrm{v}) \mathrm{NaCl}$. Growth was not observed in the absence of $\mathrm{NaCl}$. Growth was observed at temperatures between 20 and $45^{\circ} \mathrm{C}$, with optimum growth occurring at
$37{ }^{\circ} \mathrm{C}$. Strain $\mathrm{BH} 113^{\mathrm{T}}$ grew at $\mathrm{pH}$ 7.0-9.2 in TSB containing $10 \%(\mathrm{w} / \mathrm{v}) \mathrm{NaCl}$; optimal growth was observed at $\mathrm{pH}$ 8.0. Cells of strain $\mathrm{BH} 113^{\mathrm{T}}$ from early and late growth phases showed Gram-positive reactions. Cells of the isolate were strictly aerobic, short rods, $0.4-0.6 \mu \mathrm{m}$ wide and $0.8-$ $2.5 \mu \mathrm{m}$ long. Cells of the isolate produced single, spherical, terminal endospores in swollen sporangia. Cell motility occurred by means of peritrichous flagella. Anaerobic growth was not observed under anaerobic conditions after 5 days at $30{ }^{\circ} \mathrm{C}$ on MA with $10 \%(w / v) ~ N a C l$. In Table 1 , the phenotype of strain $\mathrm{BH} 113^{\mathrm{T}}$ is summarized and compared with those of the type strains of Lentibacillus species.

The 16S rRNA gene was amplified by using a PCR with the primers Eubac 27F and 1492R (DeLong, 1992) and the PCR products were purified using the QIAquick PCR purification kit (Qiagen). Sequencing of the purified $16 \mathrm{~S}$ rRNA gene was performed using an ABI PRISM BigDye Terminator cycle sequencing kit, as recommended by the manufacturer (Applied Biosystems), and five primers (337F, 785F, 1225F, 518R and 1100R). The purified sequencing-reaction mixtures were electrophoresed automatically using an Applied Biosystems model 377 automatic DNA sequencer. The resultant 16S rRNA gene sequence was compared with $16 \mathrm{~S}$ rRNA gene sequences available from GenBank by using the BLAST program and was aligned with closely related sequences by using CLUSTAL w software (Thompson et al., 1994). Sequence similarity values were computed using SIMILARITY MATRIX, version 1.1 (Ribosomal Database Project II; http://rdp.cme.msu.edu/; Cole et al., 2007). Gaps at the $5^{\prime}$ - and $3^{\prime}$ - ends of the alignment were omitted from further analysis. Phylogenetic trees were constructed using three different methods, the neighbour-joining, maximum-likelihood and maximumparsimony algorithms, available in PHYLIP version 3.6 (Felsenstein, 2002). Evolutionary distance matrices were calculated according to the algorithm of Kimura's twoparameter model (Kimura, 1980) for the neighbourjoining method. To evaluate the stability of the phylogenetic tree, a bootstrap analysis (1000 replications) was performed with the SEQBOOT, DNADIST, NEIGHBOR and CONSENSE programs in the PHYLIP package.

The almost-complete 16S rRNA gene sequence (1518 nt) of strain $\mathrm{BH} 113^{\mathrm{T}}$ was obtained and used for an initial BLAST search in GenBank and phylogenetic analysis. Phylogenetic analysis based on $16 \mathrm{~S}$ rRNA gene sequences showed that strain $\mathrm{BH} 113^{\mathrm{T}}$ formed a distinct line within the genus Lentibacillus and was located in a clade with the type strain of L. lacisals $i$ in the neighbour-joining analysis (Fig. 1). The topologies of the phylogenetic trees obtained using the maximum-likelihood and maximum-parsimony algorithms were similar to that obtained using the neighbour-joining analysis, i.e. strain $\mathrm{BH} 113^{\mathrm{T}}$ was positioned in a clade with the type strains of $L$. juripiscarius, $L$. kapialis, $L$. salicampi, L. halophilus, L. salinarum, $L$. halodurans and $L$. salarius (data not shown). The levels of 16S rRNA gene sequence similarity between strain $\mathrm{BH} 113^{\mathrm{T}}$ and L. lacisalsi 
Table 1. Characteristics that serve to differentiate strain $\mathrm{BH} 113^{\top}$ from type strains of related members of the genus Lentibacillus

Strains: 1, BH113 ${ }^{\mathrm{T}}$; 2, L. lacisalsi KCTC $3915^{\mathrm{T}}$ (data from Lim et al., 2005b); 3, L. juripiscarius JCM $12147^{\mathrm{T}}$ (Namwong et al., 2005); 4, L. kapialis JCM $12580^{\mathrm{T}}$ (Pakdeeto et al., 2007); 5, L. salarius KCTC 3911 ${ }^{\mathrm{T}}$ (Jeon et al., 2005a); 6, L. halodurans DSM 18342 ${ }^{\mathrm{T}}$ (Yuan et al., 2007); 7, L. salicampi JCM $11462^{\mathrm{T}}$ (Yoon et al., 2002); 8, L. halophilus JCM $12149^{\mathrm{T}}$ (Tanasupawat et al., 2006); 9, L. salinarum AHS- $1^{\mathrm{T}}$ (Lee et al., 2008). All strains were catalase-positive, urease-negative rods. +, Positive; -, negative; w, weak; NA, no data available; ai, anteiso; i, iso.

\begin{tabular}{|c|c|c|c|c|c|c|c|c|c|}
\hline Characteristic & 1 & 2 & 3 & 4 & 5 & 6 & 7 & 8 & 9 \\
\hline Spore shape & Spherical & Spherical & Oval & Spherical & $\begin{array}{c}\text { Spherical/ } \\
\text { oval }\end{array}$ & Spherical/oval & $\begin{array}{c}\text { Spherical/ } \\
\text { oval }\end{array}$ & Spherical & Oval \\
\hline Pigmentation & Light yellow & - & - & Red & - & - & - & - & - \\
\hline Motility & + & + & - & - & + & - & + & + & + \\
\hline $\begin{array}{l}\text { Colony diameter } \\
(\mathrm{mm})\end{array}$ & $0.2-0.3$ & NA & $0.9-3.9$ & $1.2-3.0$ & NA & $4-5$ & $1.0-2.0$ & $0.2-0.6$ & $0.5-1.2$ \\
\hline \multirow[t]{2}{*}{ Cell size $(\mu \mathrm{m})$} & $0.4-0.6 \times$ & $0.4-0.6 \times$ & $0.4-0.5 \times$ & $0.2-0.4 \times$ & $0.2-0.3 \times$ & $0.5 \times 1.5-2.5$ & $0.4-0.7 \times$ & $0.4-0.6 \times$ & $0.7-1.2 \times$ \\
\hline & $0.8-2.5$ & $1.2-3.0$ & $1.5-6.0$ & $0.8-2.5$ & $1.5-3.0$ & & $2.0-4.0$ & $1.0-3.0$ & $2.0-4.0$ \\
\hline \multicolumn{10}{|c|}{ Temperature for growth $\left({ }^{\circ} \mathrm{C}\right)$} \\
\hline Range & $20-45$ & $15-40$ & $10-45$ & $15-45$ & $15-50$ & $22-45$ & $15-40$ & $15-42$ & $15-45$ \\
\hline Optimum & 37 & $30-32$ & 37 & 37 & $30-35$ & 30 & 30 & $30-37$ & $37-40$ \\
\hline \multicolumn{10}{|c|}{$\mathrm{NaCl}$ concentration for growth $(\%, \mathrm{w} / \mathrm{v})$} \\
\hline Range & $5-15$ & $5-25$ & $3-30$ & $5-30$ & $1-20$ & $5-30$ & $2-23$ & $12-30$ & $3-24$ \\
\hline Optimum & 10 & $12-15$ & 10 & 15 & $12-14$ & $8-12$ & $4-8$ & $20-26$ & $10-12$ \\
\hline \multicolumn{10}{|l|}{$\mathrm{pH}$ for growth } \\
\hline Range & $7.0-9.2$ & $7.0-9.5$ & $5.0-9.0$ & $5.0-9.0$ & $6.0-8.0$ & $6.0-9.0$ & $6.0-8.0$ & $6.0-8.0$ & $6.0-9.5$ \\
\hline Optimum & 8.0 & 8.0 & 7.0 & 7.0 & $7.0-7.5$ & $7.0-7.5$ & NA & $7.0-7.5$ & $6.5-7.0$ \\
\hline Oxidase activity & + & + & + & + & - & + & + & + & + \\
\hline Nitrate reduction & + & + & + & + & + & - & + & - & + \\
\hline \multicolumn{10}{|l|}{ Hydrolysis of: } \\
\hline Aesculin & - & - & - & - & + & - & - & - & + \\
\hline Casein & - & - & + & - & - & - & + & - & - \\
\hline Tween 80 & - & - & + & - & - & - & + & - & - \\
\hline \multicolumn{10}{|c|}{ Acid production from: } \\
\hline L-Arabinose & - & + & - & - & + & $\mathrm{NA}$ & - & - & - \\
\hline Cellobiose & - & NA & - & - & NA & - & $\mathrm{w}$ & - & - \\
\hline D-Fructose & + & + & + & + & + & + & - & - & - \\
\hline D-Galactose & - & NA & - & + & NA & - & $\mathrm{W}$ & - & $\mathrm{w}$ \\
\hline D-Glucose & $\mathrm{w}$ & - & + & + & + & + & + & - & + \\
\hline Lactose & - & - & - & - & + & - & - & - & - \\
\hline Maltose & - & - & - & - & + & - & - & - & - \\
\hline D-Mannitol & $\mathrm{w}$ & - & - & + & $\mathrm{w}$ & - & - & - & - \\
\hline D-Mannose & - & - & - & $\mathrm{W}$ & + & + & $\mathrm{w}$ & - & - \\
\hline D-Ribose & - & + & + & + & + & - & - & - & + \\
\hline Salicin & - & - & - & - & - & - & $\mathrm{W}$ & - & - \\
\hline Sucrose & - & NA & $\mathrm{w}$ & $\mathrm{W}$ & NA & - & - & - & - \\
\hline Trehalose & + & - & - & - & $\mathrm{w}$ & - & - & - & - \\
\hline D-Xylose & + & $\mathrm{w}$ & + & - & + & - & - & - & - \\
\hline Major fatty acids & $\begin{array}{l}\text { ai- } C_{15: 0} \\
\text { i-C } \\
\text { i- } C_{14: 0}\end{array}$ & $\begin{array}{l}\text { ai- } C_{15: 0} \\
\mathrm{i}-\mathrm{C}_{17: 0} \\
\mathrm{i}-\mathrm{C}_{16: 0}\end{array}$ & $\begin{array}{l}\text { ai- } C_{15: 0} \\
\text { i- } C_{16: 0} \\
\text { ai- } C_{17: 0}\end{array}$ & $\begin{array}{l}\text { ai- } C_{15: 0} \\
\text { i-C }-C_{16: 0} \\
i-C_{14: 0}\end{array}$ & $\begin{array}{l}\text { ai- } C_{15: 0} \\
\text { i- } C_{16: 0} \\
\text { i-C } C_{14: 0}\end{array}$ & $\begin{array}{l}\text { ai- } \mathrm{C}_{15: 0} \\
\mathrm{i}-\mathrm{C}_{15: 0} \\
\text { ai- } \mathrm{C}_{17: 0}\end{array}$ & $\begin{array}{c}\text { ai- } C_{15: 0} \\
\text { i- } C_{17: 0} \\
\text { i- } C_{16: 0}\end{array}$ & $\begin{array}{c}\text { ai- } C_{15: 0} \\
\text { i- } C_{17: 0} \\
C_{16: 0}\end{array}$ & $\begin{array}{c}\text { ai- } C_{15: 0} \\
\text { i- } C_{17: 0} \\
C_{16: 0}\end{array}$ \\
\hline Polar lipids ${ }^{\star}$ & PG, DPG & PG, DPG & PG, DPG, GL & PG, DPG & PG, DPG & PG, DPG, GL & PG, DPG & PG, DPG, GL & PG, DPG, GL \\
\hline $\begin{array}{l}\text { DNA G }+ \text { C } \\
\text { content }(\mathrm{mol} \%)\end{array}$ & 46.2 & 44 & 43.4 & 41.6 & 43 & 43.4 & 42.4 & 42.4 & 49.0 \\
\hline
\end{tabular}

${ }^{\star}$ PG, Phosphatidylglycerol; DPG, diphosphatidylglycerol; GL, unknown glycolipid(s).

KCTC $3915^{\mathrm{T}}$, L. juripiscarius JCM $12147^{\mathrm{T}}$, L. kapialis JCM $12580^{\mathrm{T}}$, L. salarius KCTC $3911^{\mathrm{T}}$, L. halodurans DSM $18342^{\mathrm{T}}$, L. salinarum AHS- ${ }^{\mathrm{T}}$, L. salicampi JCM $11462^{\mathrm{T}}$ and L. halophilus JCM $12149^{\mathrm{T}}$ were 96.7, 96.3, 96.1, 96.0, 95.7,
95.7, 95.5 and 94.3\%, respectively. Furthermore, strain $\mathrm{BH} 113^{\mathrm{T}}$ showed 93.8-95.4\% $16 \mathrm{~S}$ rRNA gene sequence similarity with respect to members of the genus Virgibacillus. These levels of sequence similarity were 


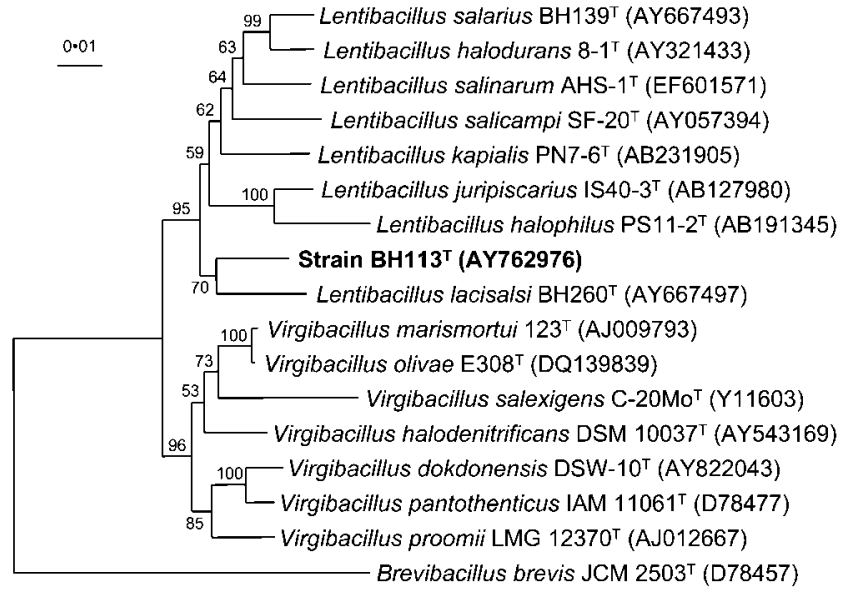

Fig. 1. Neighbour-joining phylogenetic tree, based on 16S rRNA gene sequences, showing the relationships between strain $\mathrm{BH} 113^{\top}$ and related taxa. Bootstrap percentages (based on 1000 replicates) are shown, where more than $50 \%$. Accession numbers are given in parentheses. Brevibacillus brevis JCM $2503^{\top}$ was used as the outgroup. Bar, 0.01 changes per nucleotide position.

sufficient to indicate that strain $\mathrm{BH} 113^{\mathrm{T}}$ is a member of a novel species (Rosselló-Mora \& Amann, 2001; Stackebrandt et al., 2002).

GC analysis of fatty acid methyl esters was performed, starting with cells grown at $37{ }^{\circ} \mathrm{C}$ for 3 days on MA with $10 \%(\mathrm{w} / \mathrm{v}) \mathrm{NaCl}$, according to the instructions of the Microbial Identification System (MIDI; Microbial ID). Analyses of the peptidoglycan, polar lipids and isoprenoid quinones were carried out using the methods described by Komagata \& Suzuki (1987). The DNA G + C content of strain $\mathrm{BH} 113^{\mathrm{T}}$ was determined by using reversed-phase HPLC according to the method of Tamaoka \& Komagata (1984).

The major isoprenoid quinone of strain $\mathrm{BH} 113^{\mathrm{T}}$ was MK7. The fatty acid profile of the strain was characterized by the presence of branched and saturated fatty acids such as anteiso- $\mathrm{C}_{15: 0}(37.7 \%)$, iso- $\mathrm{C}_{16: 0}(24.8 \%)$ and anteiso$\mathrm{C}_{17: 0}(15.0 \%)$ as the major fatty acids, in common with the type strains of Lentibacillus species. Although this fatty acid profile was similar to that of L. lacisalsi KCTC $3915^{\mathrm{T}}$, which is currently the closest relative on the basis of $16 \mathrm{~S}$ rRNA gene sequences, the fatty acid compositions of the two micro-organisms were somewhat different (Table 2). Analysis of the cell-wall peptidoglycan indicated that the diagnostic diamino acid of strain $\mathrm{BH} 113^{\mathrm{T}}$ was mesodiaminopimelic acid (A1 $\gamma$ type). This peptidoglycan type is characteristic of Lentibacillus species (Yoon et al., 2002). The major polar lipids of the strain $\mathrm{BH}_{113^{\mathrm{T}}}$ were diphosphatidylglycerol and phosphatidylglycerol, as in $L$. lacisalsi KCTC $3915^{\mathrm{T}}$. The genomic DNA G $+\mathrm{C}$ content of strain $\mathrm{BH} 113^{\mathrm{T}}$ was $46.2 \mathrm{~mol} \%$. In their emended description of the genus Lentibacillus, Jeon et al. (2005a) gave a range of $\mathrm{G}+\mathrm{C}$ content of $42-44 \mathrm{~mol} \%$. However, the genomic DNA G $+C$ content of L. salinarum is $49 \mathrm{~mol} \%$ (Lee et al., 2008), suggesting a wider range of $\mathrm{G}+\mathrm{C}$ content within the genus. The genomic DNA $\mathrm{G}+\mathrm{C}$ content of strain $\mathrm{BH} 113^{\mathrm{T}}$ was therefore within this extended range for the genus Lentibacillus, and the other chemotaxonomic properties, including the major fatty acid profile, the major isoprenoid quinone and the cell-wall type, were typical of those of the genus Lentibacillus (Table 1).

Table 2. Cellular fatty acid compositions of strain $\mathrm{BH} 113^{\top}$ and type strains of related members of the genus Lentibacillus

Strains: 1, BH113 ${ }^{\mathrm{T}}$; 2, L. lacisalsi KCTC $3915^{\mathrm{T}}$ (data from Lim et al., 2005b); 3, L. juripiscarius JCM $12147^{\mathrm{T}}$ (Namwong et al., 2005); 4, L. kapialis JCM $12580^{\mathrm{T}}$ (Pakdeeto et al., 2007); 5, L. salarius KCTC $3911^{\mathrm{T}}$ (Jeon et al., 2005a); 6, L. halodurans DSM 18342 ${ }^{\mathrm{T}}$ (Yuan et al., 2007); 7, L. salicampi JCM $11462^{\mathrm{T}}$ (Yoon et al., 2002); 8, L. halophilus JCM 12149 ${ }^{\mathrm{T}}$ (Tanasupawat et al., 2006); 9, L. salinarum AHS- $1^{\mathrm{T}}$ (Lee et al., 2008). -, Not detected or no data available.

\begin{tabular}{|c|c|c|c|c|c|c|c|c|c|}
\hline Fatty acid & 1 & 2 & 3 & 4 & 5 & 6 & 7 & 8 & 9 \\
\hline \multicolumn{10}{|l|}{ Saturated } \\
\hline $\mathrm{C}_{14: 0}$ & - & - & 0.2 & 0.2 & 0.2 & - & - & 0.9 & 0.6 \\
\hline$C_{16: 0}$ & 3.5 & 1.3 & 0.8 & 0.7 & 1.0 & 2.2 & 1.4 & 3.0 & 3.4 \\
\hline \multicolumn{10}{|l|}{ Unsaturated } \\
\hline $\mathrm{C}_{16: 1} \omega 7 c$ alcohol & - & 1.5 & 0.6 & - & - & - & 0.5 & - & 0.4 \\
\hline iso- $\mathrm{C}_{14: 0}$ & 13.9 & 5.7 & 10.2 & 14.8 & 13.9 & 3.1 & 12.0 & 0.4 & 3.6 \\
\hline iso- $\mathrm{C}_{15: 0}$ & 3.6 & 8.0 & 4.9 & 6.9 & 16.5 & 20.7 & 3.4 & 3.1 & 1.6 \\
\hline anteiso- $\mathrm{C}_{15: 0}$ & 37.7 & 50.8 & 45.1 & 38.3 & 25.3 & 42.4 & 38.6 & 58.0 & 54.0 \\
\hline iso- $\mathrm{C}_{16: 0}$ & 24.8 & 12.0 & 20.2 & 23.4 & 26.5 & 7.7 & 30.1 & 1.9 & 7.2 \\
\hline iso- $\mathrm{C}_{17: 0}$ & - & 1.9 & 0.5 & 0.9 & 4.4 & 5.3 & 0.7 & 0.8 & 0.7 \\
\hline anteiso- $\mathrm{C}_{17: 0}$ & 15.0 & 18.2 & 16.7 & 14.1 & 11.5 & 17.2 & 13.4 & 27.5 & 27.0 \\
\hline
\end{tabular}


Therefore, on the basis of the results of our polyphasic study, strain $\mathrm{BH} 113^{\mathrm{T}}$ represents a novel species of the genus Lentibacillus, for which the name Lentibacillus salis sp. nov. is proposed.

\section{Description of Lentibacillus salis sp. nov.}

Lentibacillus salis (sal'is. L. gen. n. salis of salt).

Cells are approximately $0.4-0.6 \mu \mathrm{m}$ wide and $0.8-2.5 \mu \mathrm{m}$ long and are strictly aerobic, Gram-positive, motile rods with peritrichous flagella. Single, terminal, spherical endospores are formed in swollen sporangia. Colonies are light yellow, low-convex and circular on MA supplemented with $10 \%(\mathrm{w} / \mathrm{v}) \mathrm{NaCl}$. Growth occurs at $20-45{ }^{\circ} \mathrm{C}$ (optimally at $37^{\circ} \mathrm{C}$ ), $\mathrm{pH} 7.0-9.2$ (optimally at $\mathrm{pH} 8.0$ ) and $5-15 \%(\mathrm{w} / \mathrm{v})$ $\mathrm{NaCl}$ (optimally at $10 \%$ ). Nitrate is reduced to nitrite. Hydrolysis of urea, L-tyrosine, hypoxanthine, casein, starch, Tween 80, aesculin, gelatin, DNA and xanthine is not observed. D-Glucose, trehalose, D-xylose, D-mannitol and Dfructose are utilized as carbon sources, D-ribose, rhamnose, glycerol, lactose, adonitol, arbutin and D-mannose are utilized weakly and maltose, D-arabinose, raffinose, salicin and melibiose are not utilized. Acids are produced from adonitol, arbutin, D-fructose, trehalose and D-xylose, produced weakly from D-glucose and D-mannitol and not produced at all from cellobiose, D-galactose, glycerol, lactose, maltose, D-mannose, melibiose, raffinose, D-ribose, salicin or sucrose. The major isoprenoid quinone is MK-7. The cell wall contains meso-diaminopimelic acid (A1 $\gamma$ type). The predominant polar lipids are phosphatidylglycerol and diphosphatidylglycerol. The major fatty acids are anteiso$\mathrm{C}_{15: 0}$, iso- $\mathrm{C}_{16: 0}$ and anteiso- $\mathrm{C}_{17: 0}$. The DNA G $+\mathrm{C}$ content of the type strain is $46.2 \mathrm{~mol} \%$ (by HPLC).

The type strain, BH113 ${ }^{\mathrm{T}}\left(=\right.$ KCTC $3936^{\mathrm{T}}=$ DSM $\left.16817^{\mathrm{T}}\right)$, was isolated from the soil of Ayakekum salt lake in Xinjiang Province, China.

\section{Acknowledgements}

This work was supported by the 21C Frontier Microbial Genomics and Application Center Program (Ministry of Science and Technology, Republic of Korea) and by a grant from the KRIBB Research Initiative Program.

\section{References}

An, S.-Y., Asahara, M., Goto, K., Kasai, H. \& Yokota, A. (2007). Terribacillus saccharophilus gen. nov., sp. nov. and Terribacillus halophilus sp. nov., spore-forming bacteria isolated from field soil in Japan. Int J Syst Evol Microbiol 57, 51-55.

Carrasco, I. J., Márquez, M. C., Xue, Y., Ma, Y., Cowan, D. A., Jones, B. E., Grant, W. D. \& Ventosa, A. (2007). Salsuginibacillus kocurii gen. nov., sp. nov., a moderately halophilic bacterium from soda-lake sediment. Int J Syst Evol Microbiol 57, 2381-2386.

Cole, J. R., Chai, B., Farris, R. J., Wang, Q., Kulam-Syed-Mohideen, A. S., McGarrell, D. M., Bandela, A. M., Cardenas, E., Garrity, G. M. \& Tiedje, J. M. (2007). The ribosomal database project (RDP-II): introducing $m y R D P$ space and quality controlled public data. Nucleic Acids Res 35 (Database issue), D169-D172.

Cowan, S. T. \& Steel, K. J. (1965). Manual for the Identification of Medical Bacteria. London: Cambridge University Press.

DeLong, E. F. (1992). Archaea in coastal marine environments. Proc Natl Acad Sci U S A 89, 5685-5689.

Echigo, A., Fukushima, T., Mizuki, T., Kamekura, M. \& Usami, R. (2007). Halalkalibacillus halophilus gen. nov., sp. nov., a novel moderately halophilic and alkaliphilic bacterium isolated from a nonsaline soil sample in Japan. Int J Syst Evol Microbiol 57, 1081-1085.

Felsenstein, J. (2002). PHYLIP (phylogeny inference package), version 3.6a. Distributed by the author. Department of Genome Sciences, University of Washington, Seattle, USA.

García, M. T., Gallego, V., Ventosa, V. \& Mellado, E. (2005). Thalassobacillus devorans gen. nov., sp. nov., a moderately halophilic, phenol-degrading, Gram-positive bacterium. Int J Syst Evol Microbiol 55, 1789-1795.

Heyndrickx, M., Lebbe, L., Kersters, K., De Vos, P., Forsyth, G. \& Logan, N. A. (1998). Virgibacillus: a new genus to accommodate Bacillus panthothenticus (Proom and Knight 1995). Emended description of Virgibacillus panthothenticus. Int J Syst Bacteriol 48, 99-106.

Ishikawa, M., Ishizaki, S., Yamamoto, Y. \& Yamasato, K. (2002). Paraliobacillus ryukyuensis gen. nov., sp. nov., a new Gram-positive, slightly halophilic, extremely halotolerant, facultative anaerobe isolated from a decomposing marine alga. J Gen Appl Microbiol 48, 269-279.

Ishikawa, M., Nakajima, K., Yanagi, M., Yamamoto, Y. \& Yamasato, K. (2003). Marinilactibacillus psychrotolerans gen. nov., sp. nov., a halophilic and alkaliphilic marine lactic acid bacterium isolated from marine organisms in temperate and subtropical areas of Japan. Int J Syst Evol Microbiol 53, 711-720.

Ishikawa, M., Nakajima, K., Itamiya, Y., Furukawa, S., Yamamoto, Y. \& Yamasato, K. (2005). Halolactibacillus halophilus gen. nov., sp. nov. and Halolactibacillus miurensis sp. nov., halophilic and alkaliphilic marine lactic acid bacteria constituting a phylogenetic lineage in Bacillus rRNA group 1. Int J Syst Evol Microbiol 55, 2427-2439.

Jeon, C. O., Lim, J.-M., Lee, J.-C., Lee, G. S., Lee, J.-M., Xu, L.-H., Jiang, C.-L. \& Kim, C.-J. (2005a). Lentibacillus salarius sp. nov., isolated from saline sediment in China, and emended description of the genus Lentibacillus. Int J Syst Evol Microbiol 55, 1339-1343.

Jeon, C. O., Lim, J.-M., Lee, J.-M., Xu, L.-H., Jiang, C.-L. \& Kim, C.-J. (2005b). Reclassification of Bacillus haloalkaliphilus Fritze 1996 as Alkalibacillus haloalkaliphilus gen. nov., comb. nov. and the description of Alkalibacillus salilacus sp. nov., a novel halophilic bacterium isolated from a salt lake in China. Int J Syst Evol Microbiol 55, 1891-1896.

Kim, Y.-G., Hwang, C. Y., Yoo, K. W., Moon, H. T., Yoon, J.-H. \& Cho, B. C. (2007). Pelagibacillus goriensis gen. nov., sp. nov., a moderately halotolerant bacterium isolated from coastal water off the east coast of Korea. Int J Syst Evol Microbiol 57, 1554-1560.

Kimura, M. (1980). A simple method for estimating evolutionary rates of base substitutions through comparative studies of nucleotide sequences. J Mol Evol 16, 111-120.

Komagata, K. \& Suzuki, K. (1987). Lipid and cell-wall analysis in bacterial systematics. Methods Microbiol 19, 161-207.

Lányí, B. (1987). Classical and rapid identification methods for medically important bacteria. Methods Microbiol 19, 1-67.

Lee, J. C., Lim, J. M., Park, D. J., Jeon, C. O., Li, W. J. \& Kim, C. J. (2006). Bacillus seohaeanensis sp. nov., a halotolerant bacterium that contains L-lysine in its cell wall. Int J Syst Evol Microbiol 56, 1893-1898. 
Lee, S.-Y., Choi, W.-Y., Oh, T.-K. \& Yoon, J.-H. (2008). Lentibacillus salinarum sp. nov., isolated from a marine solar saltern in Korea. Int $J$ Syst Evol Microbiol 58, 45-49.

Leifson, E. (1963). Determination of carbohydrate metabolism of marine bacteria. J Bacteriol 85, 1183-1184.

Lim, J.-M., Jeon, C. O., Song, S. M. \& Kim, C.-J. (2005a). Pontibacillus chungwhensis gen. nov., sp. nov., a moderately halophilic Grampositive bacterium from a solar saltern in Korea. Int J Syst Evol Microbiol 55, 165-170.

Lim, J.-M., Jeon, C. O., Song, S. M., Lee, J.-C., Ju, Y. J., Xu, L. H., Jiang, C.-L. \& Kim, C.-J. (2005b). Lentibacillus lacisalsi sp. nov., a moderately halophilic bacterium isolated from a saline lake in China. Int J Syst Evol Microbiol 55, 1805-1809.

Lu, J., Nogi, Y. \& Takami, H. (2001). Oceanobacillus iheyensis gen. nov., sp. nov., a deep-sea extremely halotolerant and alkaliphilic species isolated from a depth of $1050 \mathrm{~m}$ on the Iheya Ridge. FEMS Microbiol Lett 205, 291-297.

Nakamura, K., Haruta, S., Ueno, S., Ishii, M., Yokota, A. \& Igarashi, Y. (2004). Cerasibacillus quisquiliarum gen. nov., sp. nov., isolated from a semi-continuous decomposing system of kitchen refuse. Int J Syst Evol Microbiol 54, 1063-1069.

Namwong, S., Tanasupawat, S., Smitinont, T., Visessanguan, W., Kudo, T. \& Itoh, T. (2005). Isolation of Lentibacillus salicampi strains and Lentibacillus juripiscarius sp. nov. isolated from fish sauce in Thailand. Int J Syst Evol Microbiol 55, 315-320.

Niimura, Y., Koh, E., Yanagida, F., Suzuki, K., Komagata, K. \& Kozaki, M. (1990). Amphibacillus xylanus gen. nov., sp. nov., a facultatively anaerobic sporeforming xylan-digesting bacterium which lacks cytochrome, quinone, and catalase. Int J Syst Bacteriol 40, 297-301.

Nunes, I., Tiago, I., Pires, A. L., da Costa, M. S. \& Veríssimo, A. (2006). Paucisalibacillus globulus gen. nov., sp. nov., a Gram-positive bacterium isolated from potting soil. Int J Syst Evol Microbiol 56, 1841-1845.

Oren, A. (2002). Diversity of halophilic microorganisms: environments, phylogeny, physiology, and applications. J Ind Microbiol Biotechnol 28, 56-63.

Pakdeeto, A., Tanasupawat, S., Thawai, C., Moonmangmee, S., Kudo, T. \& Itoh, T. (2007). Lentibacillus kapialis sp. nov., from fermented shrimp paste in Thailand. Int J Syst Evol Microbiol 57, 364-369.

Ren, P. G. \& Zhou, P. J. (2005a). Tenuibacillus multivorans gen. nov., sp. nov., a moderately halophilic bacterium isolated from saline soil in Xin-Jiang, China. Int J Syst Evol Microbiol 55, 95-99.

Ren, P.-G. \& Zhou, P.-J. (2005b). Salinibacillus aidingensis gen. nov., sp. nov. and Salinibacillus kushneri sp. nov., moderately halophilic bacteria isolated from a neutral saline lake in Xin-Jiang, China. Int $J$ Syst Evol Microbiol 55, 949-953.

Rosselló-Mora, R. \& Amann, R. (2001). The species concept for prokaryotes. FEMS Microbiol Rev 25, 39-67.

Schlesner, H., Lawson, P. A., Collins, M. D., Weiss, N., Wehmeyer, U., Völker, H. \& Thomm, M. (2001). Filobacillus milensis gen. nov., sp. nov., a new halophilic spore-forming bacterium with Orn-D-Glu-type peptidoglycan. Int J Syst Evol Microbiol 51, 425-431.

Smibert, R. M. \& Krieg, N. R. (1981). General characterization. In Manual of Methods for General Microbiology, pp. 409-443. Edited by P. Gerhardt, R. G. E. Murray, R. N. Costilow, E. W. Nester, W. A. Wood, N. R. Krieg \& G. B. Phillips. Washington, DC: American Society for Microbiology.

Smibert, R. M. \& Krieg, N. R. (1994). Phenotypic characterization. In Methods for General and Molecular Bacteriology, pp. 607-654. Edited by P. Gerhardt, R. G. E. Murray, W. A. Wood \& N. R. Krieg Washington, DC: American Society for Microbiology.

Spring, S., Ludwig, W., Marquez, M. C., Ventosa, A. \& Schleifer, K.-H. (1996). Halobacillus gen. nov., with descriptions of Halobacillus litoralis sp. nov., and Halobacillus trueperi sp. nov., and transfer of Sporosarcina halophila to Halobacillus halophilus comb. nov. Int J Syst Bacteriol 46, 492-496.

Stackebrandt, E., Frederiksen, W., Garrity, G. M., Grimont, P. A., Kämpfer, P., Maiden, M. C., Nesme, X., Rosselló-Mora, R., Swings, J. \& other authors (2002). Report of the ad hoc committee for the reevaluation of the species definition in bacteriology. Int J Syst Evol Microbiol 52, 1043-1047.

Tamaoka, J. \& Komagata, K. (1984). Determination of DNA base composition by reversed-phase high-performance liquid chromatography. FEMS Microbiol Lett 25, 125-128.

Tanasupawat, S., Pakdeeto, A., Namwong, S., Thawai, C., Kudo, T. \& Itoh, T. (2006). Lentibacillus halophilus sp. nov., from fish sauce in Thailand. Int J Syst Evol Microbiol 56, 1859-1863.

Tanasupawat, S., Namwong, S., Kudo, T. \& Itoh, T. (2007). Piscibacillus salipiscarius gen. nov., sp. nov., a moderately halophilic bacterium from fermented fish (pla-ra) in Thailand. Int J Syst Evol Microbiol 57, 1413-1417.

Thompson, J. D., Higgins, D. G. \& Gibson, T. J. (1994). ClUSTAL W: improving the sensitivity of progressive multiple sequence alignment through sequence weighting, position-specific gap penalties and weight matrix choice. Nucleic Acids Res 22, 4673-4680.

Ventosa, A., García, M. T., Kamekura, M., Onishi, H. \& RuizBerraquero, M. (1989). Bacillus halophilus sp. nov., a moderately halophilic Bacillus species. Syst Appl Microbiol 12, 162-165.

Ventosa, A., Nieto, J. J. \& Oren, A. (1998). Biology of moderately halophilic aerobic bacteria. Microbiol Mol Biol Rev 62, 504-544.

Wainø, M., Tindall, B. J., Schumann, P. \& Ingvorsen, K. (1999). Gracilibacillus gen. nov., with description of Gracilibacillus halotolerans gen. nov., sp. nov.; transfer of Bacillus dipsosauri to Gracilibacillus dipsosauri comb. nov., and Bacillus salexigens to the genus Salibacillus gen. nov., as Salibacillus salexigens comb. nov. Int J Syst Bacteriol 49, 821-831.

Xue, Y., Zhang, X., Zhou, C., Zhao, Y., Cowan, D. A., Heaphy, S., Grant, W. D., Jones, B. E., Ventosa, A. \& Ma, Y. (2006). Caldalkalibacillus thermarum gen. nov., sp. nov., a novel alkalithermophilic bacterium from a hot spring in China. Int J Syst Evol Microbiol 56, 1217-1221.

Yoon, J.-H., Weiss, N., Lee, K.-C., Lee, I.-S., Kang, K. H. \& Park, Y.-H. (2001). Jeotgalibacillus alimentarius gen. nov., sp. nov., a novel bacterium isolated from jeotgal with L-lysine in the cell wall, and reclassification of Bacillus marinus Rüger 1983 as Marinibacillus marinus gen. nov., comb. nov. Int J Syst Evol Microbiol 51, 2087-2093.

Yoon, J.-H., Kang, K. H. \& Park, Y.-H. (2002). Lentibacillus salicampi gen. nov., sp. nov., a moderately halophilic bacterium isolated from a salt field in Korea. Int J Syst Evol Microbiol 52, 2043-2048.

Yoon, J.-H., Kang, S.-J. \& Oh, T.-K. (2007). Reclassification of Marinococcus albus Hao et al. 1985 as Salimicrobium album gen. nov., comb. nov. and Bacillus halophilus Ventosa et al. 1990 as Salimicrobium halophilum comb. nov., and description of Salimicrobium luteum sp. nov. Int J Syst Evol Microbiol 57, 2406-2411.

Yuan, S., Ren, P., Liu, J., Xue, Y., Ma, Y. \& Zhou, P. (2007). Lentibacillus halodurans sp. nov., a moderately halophilic bacterium isolated from a salt lake in Xin-Jiang, China. Int J Syst Evol Microbiol 57, 485-488. 